amount of theory as a basis, and a book which does not supply, in each branch, the necessary minimum hardly deserves to claim the title of a "comprehensive treatise."

MaURICE SOLOMON.

\section{PIONEER IRRIGATION.}

Pioneer Irrigation for Farmers in the Colonies. By E. O. Mawson, M.Inst.C.E. With Chapters on Light Railways, by E. R. Calthrop, M.Inst.C.E. Pp. xvi+26o. (London: Crosby Lockwood and Son, 1904.)

THE preface states that " this book has been written with the object of supplying pioneer farmers, in arid countries, with information which may assist them in conserving the precarious rainfall, and utilising it for the irrigation of crops"; also that "only the most homely contrivances, such as can be constructed and worked without professional advice or skilled labour are suggested "; and that the object "throughout the volume has been to demonstrate, in the simplest possible manner, how the available watersupply--whether surface-flow or underground-can be used for irrigating crops by means of works easily constructed at a small expenditure, without fear of danger in case of failure." The book, however, is not in reality confined within these prescribed limits; for it refers to earthen dams, with puddle trench, waste weir, and outlet valve tower, masonry dams of moderate height for forming reservoirs in gorges, a masonry aqueduct of several spans, and a barrage or weir across an apparently wide river, closed along the upper portion by a series of automatic sluice-gates. The works, indeed, shown in some of the woodcuts, and especially on plates 3 to 8 , Io, and I9, could not possibly be regarded as homely contrivances, capable of being easily carried out by pioneer farmers, without skilled labour, at a small cost, and without danger to the neighbourhood in the event of failure.

The chapters on the value of irrigation and sources of water-supply, underground waters, methods of irrigation, and the cultivation of irrigated crops, vegetables, and fruit trees, contain much information which would be very useful to persons engaged in the cultivation of arid districts; but most of the works described in the chapters on dams and weirs, canals, sewage irrigation, and automatic sluice-gates, would be wholly beyond the resources of pioneer farmers. The storage of rainfall, the collection of the run-off of water in the rainy season by open tanks formed in depressions enclosed by low banks, and the drawing of underground waters from wells, are works which can be readily undertaken with great benefit by cultivators of arid lands; but the formation of large reservoirs by damming up valleys, and the raising of the water level of rivers and the conveyance of the water considerable distances in irrigation canals, constitute works which have to be carried out by a company, the local authorities, or the Government, for the irrigation of large tracts of land. Sewage irrigation, moreover, can only be made use of in the neighbourhood of large communities, and is not available amongst the sparse population of a newly-settled agricultural district.

NO. I 8 I 5 , VOL. 70]
In a chapter on automatic sluice-gates, a system of hinged gates or shutters is advocated for raising the water level of reservoirs and rivers, which has apparently been patented by one of the authors; but it is not stated that the design has been put into operation; and such automatic contrivances, as in the case of the movable shutter weirs employed long ago for the canalisation of some rivers in France, are liable to be very irregular in their action. The two concluding chapters furnish some interesting particulars about light railways, which are introduced with the view that the conveyance of the produce of irrigated lands to a market is second only in importance to the supply of water. Such works, however, with the great advantages that they afford, have to be carried out in the midst of a thriving community, where both capital and revenue are available; and they are beyond the scope of pioneer farmers who are extending cultivation into new, unoccupied districts. A long appendix is given at the end of the volume, containing various memoranda, tables, and particulars about materials and tools, which may be of service in irrigation works and farming. The book is, in fact, a short manual on irrigation works in general, with some account of the construction, suitable gauges, and rolling-stock of light railways.

\section{OUR BOOK SHELF,}

Lehrbuch der Stereochemie. By A. Werner. Pp. xvi + 474. (Jena: Gustav Fischer, I904.) Price Io marks.

THIs book had its origin in the courses of lectures on stereochemistry delivered during recent years by Prof. Werner in the University of Zurich. The systematic form of the lectures has been adhered to, but by the addition of numerous tables and many hundreds of references to original sources, the author has produced a comprehensive handbook which must prove of great utility, not only to the general chemist who wishes to know something of the advances made in stereochemistry since the conception was first put forward, but also to the specialist whose work is directly concerned with the subject. Notwithstanding the wealth of detail, the book is of moderate compass, and whilst compression in the theoretical portions is occasionally carried to such an extent as to interfere somewhat with intelligibility, yet the book is on the whole both readable and easily comprehensible. The eminence of the author as an investigator in some of the most obscure fields of stereochemical research is sufficient guarantee of his mastery of both theory and material.

The work is composed of two chief parts, of which the first deals with stereoisomerism, divided into subsections according to the elements involved. The first subsection is naturally devoted to the stereoisomeric carbon compounds, and occupies about half of the whole book. In it are treated, amongst other matters, the theory of the asymmetric carbon atom, mirror-image isomerism, racemism and the resolution of racemic compounds, determination of configuration in open chains (more particularly in the sugars and related substances) and in closed chains, the quantitative relations between rotation and the nature of the asymmetric carbon atom, cis-trans isomerism in cyclic compounds, and the geometric isomerism of ethylenic compounds. The 